\title{
Direct SW aerosol radiative forcing over Portugal
}

\author{
D. Santos ${ }^{1}$, M. J. Costa ${ }^{1,2}$, and A. M. Silva ${ }^{1,2}$ \\ ${ }^{1}$ Geophysics Centre of Évora, Univ. Évora, Évora, Portugal \\ ${ }^{2}$ Departament of Physics, Univ. Évora, Évora, Portugal
}

Received: 20 December 2007 - Published in Atmos. Chem. Phys. Discuss.: 9 May 2008

Revised: 24 July 2008 - Accepted: 28 August 2008 - Published: 2 October 2008

\begin{abstract}
In this work, the evaluation of the aerosol radiative forcing at the top of the atmosphere as well as at the surface over the south of Portugal is made, particularly in the regions of Évora $\left(38^{\circ} 34^{\prime} \mathrm{N}, 7^{\circ} 54^{\prime} \mathrm{W}\right)$ and of Cabo da Roca $\left(38^{\circ} 46^{\prime} \mathrm{N}, 9^{\circ} 38^{\prime} \mathrm{W}\right)$, during years 2004 and 2005.
\end{abstract}

The radiative transfer calculations, using the radiative transfer code Second Simulation of the Satellite Signal in the Solar Spectrum (6S), combine ground-based measurements, from Aerosol Robotic NETwork (AERONET), and satellite measurements, from MODerate Imaging Spectroradiometer (MODIS), to estimate the direct SW aerosol radiative forcing. The method developed to retrieve the surface spectral reflectance is also presented, based on ground-based measurements (AERONET) of the aerosol optical properties combined with the satellite-measured radiances (MODIS).

The instantaneous direct SW aerosol radiative forcing values obtained at the top of the atmosphere are, in the majority of the cases, negative, indicating a tendency for cooling the Earth at the top of the atmosphere. For Desert Dust aerosols, over the Évora land region, the average forcing efficiency is estimated to be $-25 \mathrm{Wm}^{-2} / \mathrm{AOT}_{0.55}$ whereas for the Cabo da Roca area, the average forcing efficiency is $-46 \mathrm{Wm}^{-2} / \mathrm{AOT}_{0.55}$. In the presence of Forest Fire aerosols, both from short and long distances, the average value of forcing efficiency at the top of the atmosphere over Cabo da Roca is found to be $-28 \mathrm{Wm}^{-2} / \mathrm{AOT}_{0.55}$ and, over Évora, $-27 \mathrm{Wm}^{-2} / \mathrm{AOT}_{0.55}$. For specific situations, discussed in this work, the average surface direct SW aerosol radiative forcing efficiency due to the Desert Dust aerosols, in Évora region, is $-66 \mathrm{Wm}^{-2} / \mathrm{AOT}_{0.55}$, whereas in Cabo da Roca region, the corresponding average value is $-38 \mathrm{Wm}^{-2} / \mathrm{AOT}_{0.55}$. Considering the Forest Fire aerosols, over Évora region, the average surface direct SW

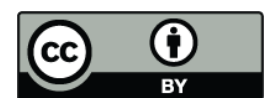

Correspondence to: D. Santos (dinas@uevora.pt) aerosol radiative forcing efficiency can vary between -36 and $-113 \mathrm{Wm}^{-2} / \mathrm{AOT}_{0.55}$, the more negative value corresponding to forest fire aerosols coming only from shorter distances.

\section{Introduction}

Aerosols play a key-role in the atmosphere by increasing back-scattered solar radiation and by absorbing solar and longwave radiation. They indirectly affect climate by changing the microphysical properties of clouds and their life span, thereby modifying the planetary albedo and precipitation regime. Depending on their properties, aerosols can have either positive or negative contributions to radiative forcing in the atmosphere. When absorbing aerosols are present in the atmosphere, a positive radiative forcing is found, producing then a warming effect. On the other hand if a negative radiative forcing is found a cooling effect is produced. However, the limited information on aerosol properties and dynamics, particularly in the troposphere, is a major uncertainty. In fact, the confidence in current climate change predictions is still very low (IPCC, 2007), thus warranting detailed investigation of aerosols.

Within Europe, Portugal is a unique location for aerosol studies because it is affected by contrasting air masses (Verver et al., 2000). Here, large unperturbed rural areas co-exist with dense pollution-generating industrial and urban agglomerates. Maritime aerosols are a pervasive component of the regional atmosphere - particularly over land adjacent to the western and southern coasts, and the region is also affected by the long-range transport of anthropogenic aerosols emitted in northern Europe, and by desert dust plumes advected from Africa. Desert dust, and frequently during summer, smoke from forest fires, account for a significant amount of the suspended particle mass. These particles are very efficient at scattering and absorbing both short and longwave

Published by Copernicus Publications on behalf of the European Geosciences Union. 
radiation, being then of primary importance for the estimation of radiative forcing due to aerosols.

Long-term monitoring is necessary for understanding climate change implications, in particular to identify major aerosol types, to characterise their spatial and temporal distribution and their optical and physical properties, and to estimate their local and regional radiative forcing. In Portugal, long-term monitoring is being undertaken with measurements from ground-based instruments at Évora, extended with measurements from Cabo da Roca (Elias et al., 2006). The instrumentation at Évora and Cabo da Roca includes a multi-wavelength, angular-resolving sun/sky photometer (Silva et al., 2003).

The present work aims to estimate the direct shortwave (SW) aerosol radiative forcing at the top of the atmosphere (TOA) over the south of Portugal, particularly in the regions of Évora and of Cabo da Roca, where ground-based measurements are taken. Also for special aerosol events the direct shortwave aerosol radiative forcing, over Évora and Cabo da Roca, is estimated at the surface. Special attention is given to significant aerosol events of desert dust and forest fires, which often occur in the territory, as described before. A second objective is aimed, which consists in developing a method for retrieving the surface spectral reflectance based on ground-based measurements of the aerosol optical properties combined with the satellite-measured radiances.

The methodology is based on radiative transfer calculations combined with surface and satellite measurements. The ground-based measurements of the aerosol optical properties provide the essential atmospheric characterization that combined with the satellite-measured radiance allow for the retrieval of the surface spectral reflectance, which is crucial for the irradiances calculations. When the surface characterization is achieved, the upwelling shortwave irradiances are calculated, using the same atmospheric characterization (obtained from the ground-based measurements of aerosol properties). The TOA direct SW aerosol radiative forcing is then determined as being the difference between the net irradiances obtained for an atmosphere loaded with aerosols and the net irradiances of a pristine atmosphere, in the shortwave spectral region. The net irradiances are given by the difference between the downwelling and upwelling shortwave TOA irradiances.

The net radiative forcing can be either positive or negative, depending on several key parameters such as the surface spectral reflectance, aerosol single scattering albedo and aerosol optical thickness (Tegen and Lacis, 1996; Liao and Seinfeld, 1998; Haywood and Boucher, 2000; Kaufman et al., 2002). The results obtained substantiate these effects, illustrating also the importance of considering the actual aerosol properties, in this case measured by ground-based instrumentation, since different aerosol types or long range transported aerosols mixing with already existing aerosols may alter their properties and originate different forcing magnitudes, sometimes changing the signs. In the major- ity of the cases, the aerosol radiative forcing values obtained are negative, indicating a tendency for cooling the Earth, at a local/regional scale.

\section{Methodology}

The methodology developed to derive de surface spectral reflectance and to estimate the aerosol radiative forcing is described next.

\subsection{Data and region of study}

The Aerosol Robotic NETwork (AERONET) is a global ground-based network of sun/sky multiwavelength radiometers that provide relatively long-term records of aerosol optical properties (Holben et al., 1998, 2001). In the region investigated in this study, data from the two stations, Évora (38.5 N, 7.9 W, 293 ma.m.s.l.) and Cabo da Roca (38.78 N, $9.5 \mathrm{~W}, 140 \mathrm{~m}$ a.m.s.1.), are available during years 2004 and 2005. The CIMEL spectral radiometer measures the direct solar irradiances with a field of view of approximately $1.2^{\circ}$ and sky radiances (at two different observing geometries), at four spectral channels $(0.441,0.675,0.87$ and $1.02 \mu \mathrm{m})$. Between morning and afternoon, direct solar radiances are measured, approximately every $15 \mathrm{~min}$, and the aerosol optical thickness (AOT), estimated, according to AERONET's official inversion product (Dubovik and King, 2000; Dubovik et al., 2002). After using the proper calibrations and corrections, the estimated accuracy is between 0.01 and 0.02 (Holben et al., 1998). Sky radiance scans are made in $0.5^{\circ}$ increments through the aureole up to $30^{\circ}$ increments in the backscattered direction along solar principal plane and solar almucantar plane. An estimated absolute accuracy of 3 to 5\% is set to the measured radiances (Dubovik et al., 2000, 2002). AERONET data used in this work are level 1.5 of the volume particle size distribution $(V(r))$, the complex refractive index $(m)$ and the AOT values at $0.441,0.673$ and $0.873 \mu \mathrm{m}$. Although the 1.5 data are not quality assured (it can be cloud contaminated), additional information from satellite data was also used to ensure the clear-sky situation.

Satellite radiance measurements from the MODerate Imaging Spectroradiometer (MODIS) installed onboard the Earth Observing System Terra and Aqua satellites, are used. MODIS has a viewing swath width of $2330 \mathrm{~km}$, and scans the entire surface of the Earth in 36 spectral bands (from 0.4 to14 $\mu \mathrm{m}$ ) (Barnes et al., 1998). The spectral bands used here are $434-448 \mathrm{~nm}, 620-670 \mathrm{~nm}$ and $841-876 \mathrm{~nm}$. The spatial resolution is for the first spectral band $1000 \times 1000 \mathrm{~m}^{2}$ and for the second and third spectral bands $250 \times 250 \mathrm{~m}^{2}$.

The study areas selected for this work are presented in the map of Fig. 2: Évora (150 km south-east of Lisbon) and Cabo da Roca (20 km west of Lisbon, on the Atlantic Ocean west coast). The Évora site coincides with the first continental Portuguese Aerosol Robotic Network (AERONET) site, 
operating since 2002. Cabo da Roca, the second continental Portuguese AERONET site, operating since December 2003, is the continental western-most site in Europe.

\subsection{Classification of the aerosol case studies}

In order to interpret the optical measurements in terms of the aerosol origins, the 72-h air mass back-trajectories, ending over Évora and Cabo da Roca regions are calculated at three pressure levels, using HYSPLIT (HYbrid Single-Particle Lagrangian Integrated Trajectory) model available from the US National Oceanic and Atmospheric Administration (NOAA) (Draxler and Hess, 1998; Draxler and Rolph, 2003; Rolph, 2003). The pressure levels chosen are $970 \mathrm{hPa}$, which represents the surface level, $850 \mathrm{hPa}$ (at about $1.5 \mathrm{~km}$ height) corresponding to the characteristic boundary layer height, where the majority of aerosols are concentrated in the absence of strong aerosol episodes, and $700 \mathrm{hPa}$ (at about $3 \mathrm{~km}$ height) to take into account the long-range transport of particles (as Saharan desert dust). For the vertical motion, the Model Vertical Velocity is considered.

The criteria used for aerosol classification is the same followed by Elias et al. (2006). Threshold values are set, for different aerosol events, on the aerosol optical thickness (AOT) at $0.441 \mu \mathrm{m}$ and $0.873 \mu \mathrm{m}$ and on the Angström exponent $\left(\alpha_{c}\right)$, between $0.441 \mu \mathrm{m}$ and $0.873 \mu \mathrm{m}$. The events considered are "Forest Fire" and "urban/industrial", when $A O T_{0.441}>0.30$ and $\alpha_{c}>1.0$. The distinction between the "Forest Fire" and "urban/industrial" events is based on the corresponding air mass backward trajectories. An aerosol event is classified as "Desert Dust" when $A O T_{0.873}>0.10$ and $\alpha_{c}<1.0$. A "Clean" situation is considered when $A O T_{0.441}<0.12$ and $A O T_{0.873}<0.04$ for any value of the Ångström exponent.

Table 1 shows the threshold values used for the aerosol events classification. "NC" indicates no conditions on this quantity.

\subsection{Retrieval of the surface spectral reflectance}

The surface spectral reflectance is derived using MODIS satellite measurements in the following three spectral bands: $0.434-0.448 \mu \mathrm{m}$ (band 9), 0.620-0.670 $\mu \mathrm{m}$ (band 1) and $0.841-0.876 \mu \mathrm{m}$ (band 2) combined with radiative transfer calculations. As mentioned before, the spatial resolution of band 9 differs from that of bands 1 and $2\left(1000 \times 1000 \mathrm{~m}^{2}\right.$ in the first case and $250 \times 250 \mathrm{~m}^{2}$ for bands 1 and 2 ). MODIS band 9 images were linearly interpolated in-between pixels in order to obtain the spatial resolution of bands 1 and 2 $\left(250 \times 250 \mathrm{~m}^{2}\right)$. This is done assuming that the surface is fairly homogeneous in each area of $1000 \times 1000 \mathrm{~m}^{2}$ so that no important features are smoothed or accentuated by the procedure. These assumptions are applicable for the areas under study (Fig. 2) and provided that, in the case of Cabo da Roca, the pixels over land are totally separated from those over the
Table 1. Criteria for the classification of the aerosol events used in this work. "NC" indicates no conditions on this quantity.

\begin{tabular}{lccc}
\hline Event type & $\mathrm{AOT}_{0.441}$ & $\mathrm{AOT}_{0.873}$ & $\alpha_{c}$ \\
\hline Clean & $<0.12$ & $<0.04$ & $\mathrm{NC}$ \\
Forest Fire/ Urban & $>0.30$ & $\mathrm{NC}$ & $>1.0$ \\
Desert Dust & $\mathrm{NC}$ & $>0.10$ & $<1.0$ \\
\hline
\end{tabular}

ocean, since pixels over the ocean are not considered in the study. The surface spectral reflectance is then determined in the three spectral intervals with the same spatial resolution of $250 \times 250 \mathrm{~m}^{2}$.

Only "clear-sky" situations are considered, that is, no clouds are present in the regions of study. MODIS data are thus collected for typically "clear-sky" days. This selection is done through visual inspection of the MODIS RGB images (http://modis-atmos.gsfc.nasa.gov/IMAGES/ index.html) over the areas of study (Fig. 2). On the other hand, the images used correspond to situations of very low aerosol loads in the atmosphere ("clean" days), as defined in Sect. 2.2. The aim of using "clean" and "clear-sky" atmospheric days is the reduction to a minimum of the impact that the atmospheric correction (due to aerosols) may have on the surface spectral reflectance retrievals. Gaseous absorption errors are reduced to a minimum since no important gas absorption bands are present in the spectral regions where the surface reflectance is determined.

The Second Simulation of the Satellite Signal in the Solar Spectrum (6S) (Vermote et al., 1997a) is the radiative transfer code used to correct the satellite measured signal for the atmospheric contribution and to model the TOA upwelling and downwelling irradiance values. This code can simulate satellite radiation measurements in cloudless atmospheres, between 0.25 and $4.0 \mu \mathrm{m}$, for a wide range of atmospheric and surface conditions (Vermote et al., 1997b). The 6S takes into account the atmospheric compounds considering 34 atmospheric levels distributed from the ground up to $100 \mathrm{~km}$ altitude, which is considered the TOA level. A standard atmospheric profile typical of mid-latitude summer or winter, according to the case under study and the aerosol properties obtained at the two AERONET stations (see Sect. 2.1) are considered.

The aerosol optical quantities are retrieved from the volume particle size distribution (with 22 logarithmically equidistant bins from 0.05 to $15 \mu \mathrm{m}$ ) and from the complex refractive index $m$, both taken from the AERONET product (level 1.5), which are then used as input to Mie calculations, since aerosol particles are assumed to be spherical (not necessarily true for desert dust aerosols). The AOT at $0.55 \mu \mathrm{m}$ is obtained using the Ångström exponent between $0.441 \mu \mathrm{m}$ and $0.873 \mu \mathrm{m}$. The Mie calculations provide the phase function, the asymmetry factor, the single scattering 


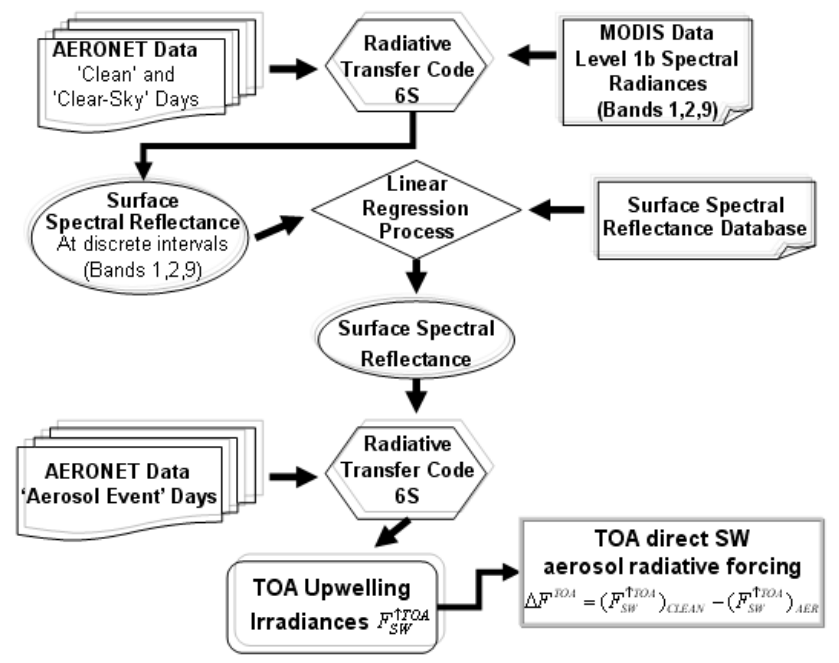

Fig. 1. Block diagram of the methodology followed in this work.

albedo and the scattering and extinction coefficients. These aerosol quantities are then used once more, to compute the upwelling irradiance at the TOA, as well as the downwelling and upwelling irradiances at the surface level.

Since the atmospheric correction parameters are known, as well as the geometry and the satellite measured spectral radiance, the surface reflectance is determined, with $6 \mathrm{~S}$ radiative transfer code, considering the surface behaves as a Lambertian reflector. The surface reflectance is thus obtained in the three spectral bands mentioned before $(0.438-0.448 \mu \mathrm{m}$, $0.620-0.670 \mu \mathrm{m}$ and $0.841-0.876 \mu \mathrm{m}$ ), with the spatial resolution of $250 \times 250 \mathrm{~m}^{2}$.

The surface spectral reflectance values obtained from MODIS data and 6S radiative transfer code $(0.438-$ $0.448 \mu \mathrm{m}, 0.620-0.670 \mu \mathrm{m}$ and $0.841-0.876 \mu \mathrm{m})$ are compared with spectral reflectance curves typical of different surface types, contained in a surface spectral reflectance database - the USGS Digital Spectral Library (see online http://speclab.cr.usgs.gov/spectral-lib.html). The satellite derived surface spectral reflectance values are compared with the spectral surface reflectance values from the USGS database and the curve that better reproduces the MODIS surface reflectance spectral behaviour is taken (see the block diagram in Fig. 1). Since the surface reflectance values obtained from MODIS and from the database for the three spectral bands are proportional, a linear relation is adjusted with the correlation coefficients varying between 0.91 and 0.99 . The linear regression calculated allows for obtaining an adjusted curve, which permits an extension of the satellite derived spectral reflectance coverage from the three above mentioned spectral bands, to the whole shortwave spectral region $(0.25-4.0 \mu \mathrm{m})$. The results obtained are presented in Sect. 3.1 (Figs. 3-4).

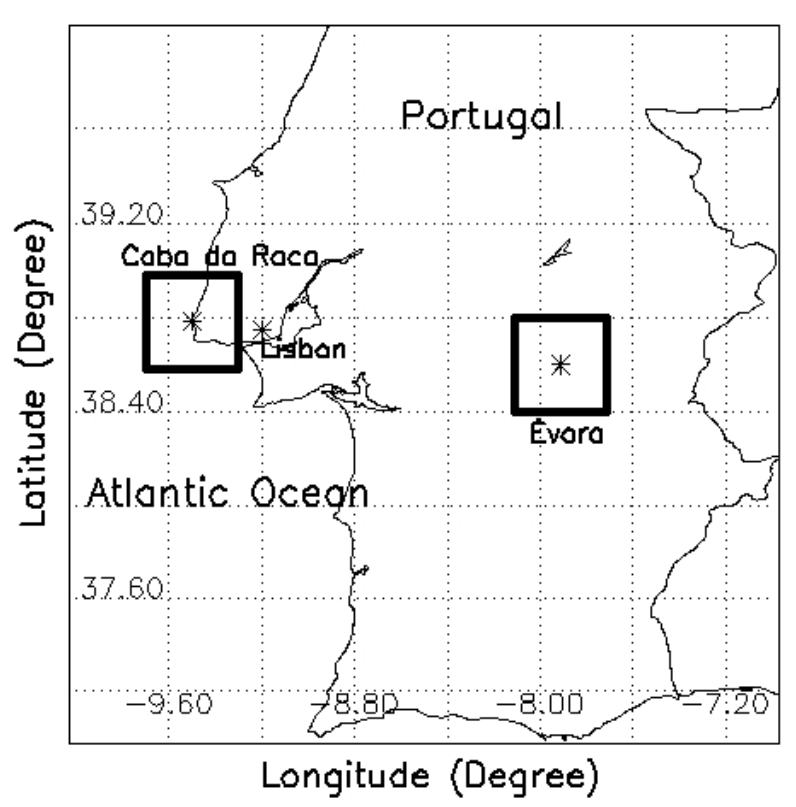

Fig. 2. Regions selected for the study: Évora and Cabo da Roca.

\subsection{Assessment of the radiative forcing for different aerosol} type events

The aerosol characterization obtained from the AERONET sites (Évora and Cabo da Roca), as well as the surface spectral reflectance retrieved, as explained in Sect. 2.3, are used to estimate the upwelling shortwave $(S W)$ irradiances at the top of the atmosphere $\left(F_{S W}^{\uparrow \mathrm{TOA}}\right)$. This is done according to the procedure described by Costa et al. (2004) for the calculation of the upwelling shortwave irradiances emerging at the TOA level that can be summarized by Eq. (1):

$F_{S W}^{\uparrow \mathrm{TOA}}=\int_{0.25}^{4}\left[\int_{0}^{2 \pi} \int_{0}^{+1} I_{\lambda}(+\mu, \phi) \cdot \mu \cdot d \mu \cdot d \phi\right] . d \lambda$

where $I_{\lambda}$ the monochromatic radiance in the zenith and azimuth directions is, $\mu$ is the cosine of the viewing zenith angle and $\phi$ is the azimuthal angle. The irradiances are also calculated for a pristine atmosphere $(\mathrm{AOT}=0)$, in order to allow for the calculation of the radiative forcing induced by several aerosol types and loads $\left(\Delta F^{\mathrm{TOA}}\right)$.

The instantaneous direct $\mathrm{SW}$ aerosol radiative forcing $(\Delta F)$ at the TOA, expressed in units of energy per unit time and area, is defined as:

$\Delta F^{\mathrm{TOA}}=F_{\mathrm{AER}}^{\text {net TOA }}-F_{\text {CLEAN }}^{\text {net TOA }}$.

The first term on the right corresponds to the total net irradiance at the TOA that suffered an external perturbation due to aerosols and the second term to the total atmospheric net irradiance at the same level that did not suffer the perturbation. For aerosol study purposes, the $\mathrm{SW}$ radiative forcing $\Delta F_{S W}$ 


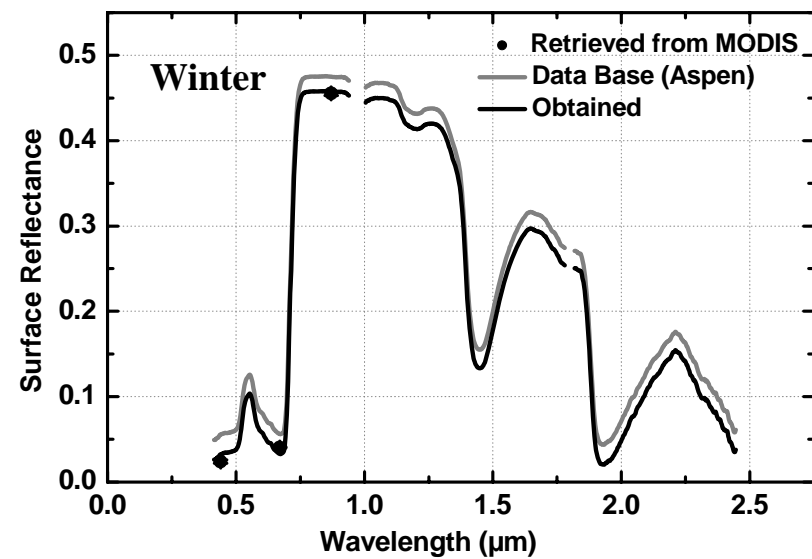

(a)

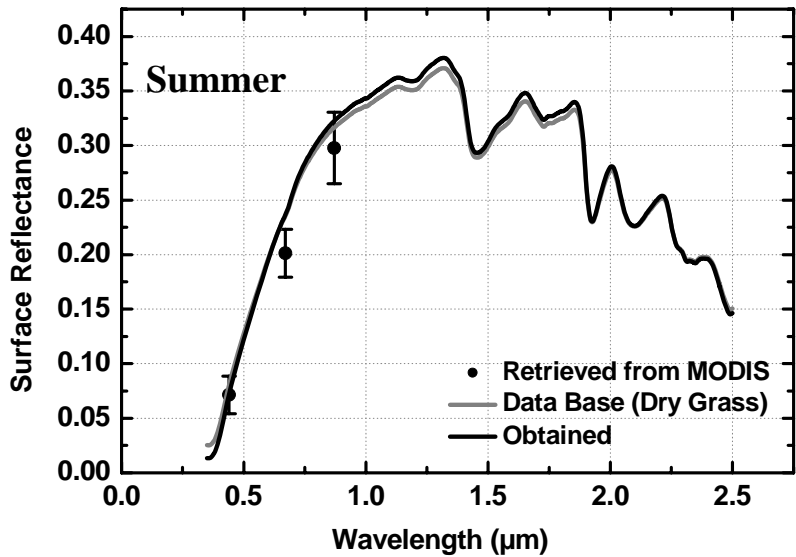

(b)

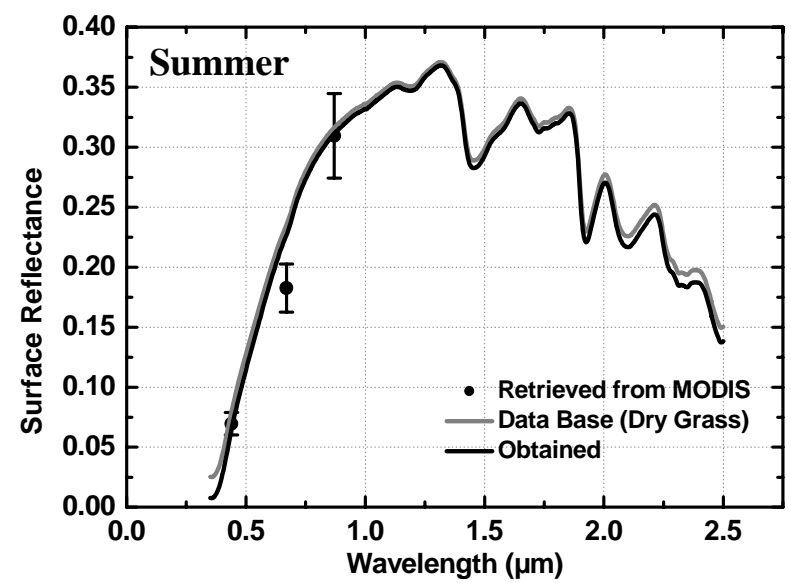

(c)

Fig. 3. Surface spectral reflectance values: from the USGS database (grey line), retrieved from MODIS (black circles) and obtained combining the database with MODIS retrievals (black line) for Évora nearby rural area, during 2004 winter (a) and summer (b) periods, and during the 2005 summer period (c).

has been considered the most adequate since the direct effects of these particles on the radiation field are mainly connected to their interaction with sunlight through the scattering and absorption processes. Hence, the shortwave radiative forcing due to an increase of the aerosol load in the atmosphere is here determined in the spectral region from 0.25 to $4.0 \mu \mathrm{m}$ (see the block diagram in Fig. 1). Equation (2) can be rewritten in terms of the downwelling and upwelling shortwave irradiances as follows:

$\Delta F_{S W}^{\mathrm{TOA}}=\left(F_{S W}^{\downarrow \mathrm{TOA}}-F_{S W}^{\uparrow \mathrm{TOA}}\right)_{\mathrm{AER}}-\left(F_{S W}^{\downarrow \mathrm{TOA}}-F_{S W}^{\uparrow \mathrm{TOA}}\right)_{\mathrm{CLEAN}}$.

Since the incident downwelling irradiance at the TOA does not depend on aerosols, the TOA direct SW aerosol radiative forcing (DSWARF) can be finally written as:

$\Delta F_{S W}^{\mathrm{TOA}}=\left(F_{S W}^{\uparrow \mathrm{TOA}}\right)_{\mathrm{CLEAN}}-\left(F_{S W}^{\uparrow \mathrm{TOA}}\right)_{\mathrm{AER}}$.

The instantaneous TOA DSWARF is calculated in this way and the results obtained are presented in Sect. 3.2.
The instantaneous DSWARF at the surface was calculated in terms of the downwelling and upwelling shortwave irradiances at the surface as follows:

$$
\begin{aligned}
& \Delta F_{S W}^{\mathrm{SURF}}= \\
& \left(F_{S W}^{\downarrow \mathrm{SURF}}-\rho_{S} F_{S W}^{\downarrow \mathrm{TSURF}}\right)_{\mathrm{AER}}-\left(F_{S W}^{\downarrow \mathrm{SURF}}-\rho_{S} F_{S W}^{\downarrow \mathrm{SURF}}\right)_{\mathrm{CLEAN}}
\end{aligned}
$$

where $\rho_{s}$ stands for the surface reflectance; the DSWARF of the entire atmosphere can be estimated, according to Ramanathan et al. (2001) as follows:

$$
\Delta F_{S W}^{\mathrm{atm}}=\Delta F_{S W}^{T O A}-\Delta F_{S W}^{\mathrm{surf}}
$$

When studying the aerosol-radiation interactions, it is very useful to define the forcing efficiency term, $\Delta F_{e}$, in order to compare a quantity that is independent of the aerosol load, depending thus only on the aerosol type and underlying 


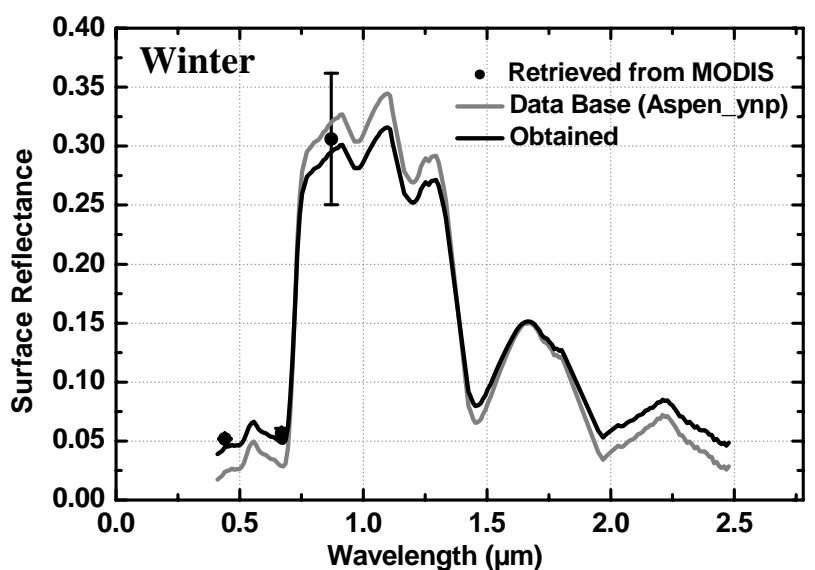

(a)

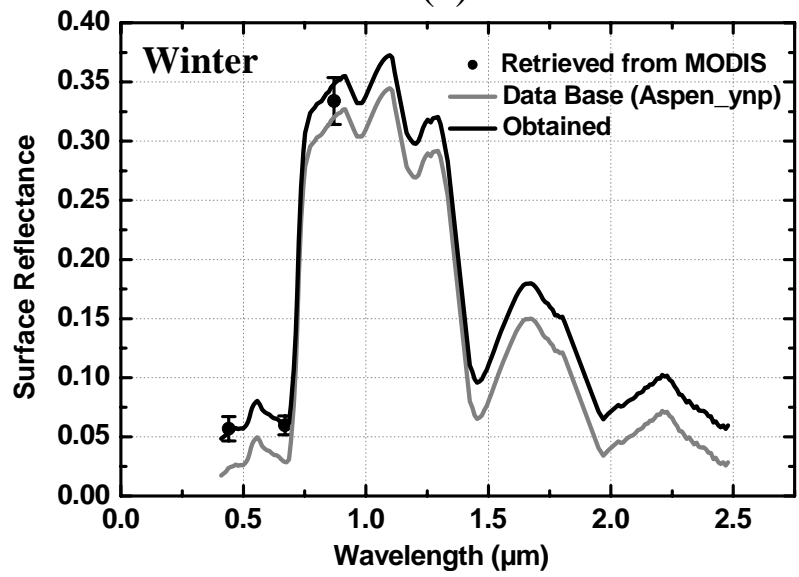

(c)

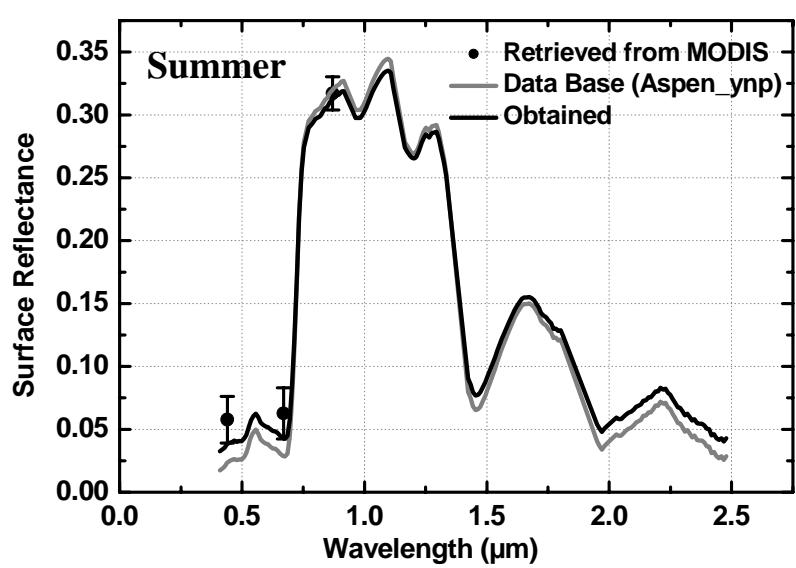

(b)

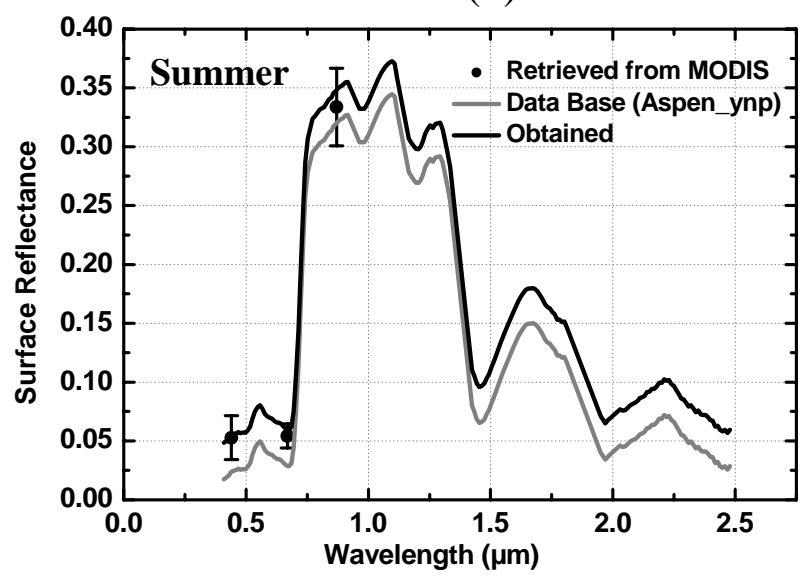

(d)

Fig. 4. Same as in Fig. 3 for Cabo da Roca land area, during 2004 winter (a) and summer (b) periods, and during 2005 spring (c) and summer (d) periods.

surface. As expressed in Eq. (7), $\Delta F_{e}$ is simply the radiative forcing per unit aerosol optical thickness:

$\Delta F_{e}=\Delta F_{S W}^{\mathrm{TOA}} / \mathrm{AOT}_{\lambda}$.

This term represents the effectiveness of the aerosol in perturbing the radiative environment.

To note that the longwave forcing of aerosols is not included in the forcing efficiencies presented in this work.

\section{Results and discussion}

\subsection{Retrieval of the surface spectral reflectance}

MODIS data are collected for typically "clean" (very low aerosol load) and "clear-sky" (no clouds) days over the area of study illustrated in the map of Fig. 2. The days selected for the study, accordingly to the criteria explained in Sect. 2.2, as well as the satellite images used, are identified in Table 2.
The satellite derived surface reflectance values obtained in three spectral bands are extended to the whole visible range (from 0.25 to $4.0 \mu \mathrm{m}$ ) as explained in Sect. 2.3. Tables 3 and 4 show the surface spectral reflectance values taken from the database $\left(\rho_{s}\right)$, as well as the mean surface spectral reflectance values retrieved from MODIS spectral bands $(0.438-0.448 \mu \mathrm{m}, 0.620-0.670 \mu \mathrm{m}$ and $0.841-$ $0.876 \mu \mathrm{m})\left(\overline{\rho_{s}}\right)$, averaged over the areas of study - Évora nearby rural region $\left(20 \times 20 \mathrm{~km}^{2}\right.$ area $)$ and Cabo da Roca land region $\left(5 \times 5 \mathrm{~km}^{2}\right.$ area), and the corresponding standard deviation values. To note that, for all situations, more than 4000 (Évora) and 250 (Cabo da Roca) MODIS pixels were considered for the average. The number differs from case to case because the pixels corresponding to concrete surfaces (cities and other urban spots) are not taken into account.

The satellite derived surface spectral reflectance values follow the spectral behaviour of the surface reflectance curve taken from the database (Figs. 3 to 4). For Évora region, in the majority of the cases, the database reflectance values are 
Table 2. MODIS granules used for the study.

\begin{tabular}{cccc}
\hline Satellite & Date & $\begin{array}{c}\text { MODIS granule } \\
\text { acquisition time (UTC) }\end{array}$ & Aerosol type \\
\hline \multirow{4}{*}{ Terra } & 5 Feb 2004 & From 11:25 to 11:30 & \\
& 21 Feb 2004 & From 11:25 to 11:30 & \\
& 20 Jul 2004 & From 10:45 to 10:50 & \\
& 14 Aug 2004 & From 10:40 to 10:45 & Clean \\
& 1 Jul 2005 & From 11:25 to 11:30 & \\
& 3 Aug 2005 & From 12:05 to 12:10 & \\
& 27 Aug 2005 & From 11:15 to 11:20 & \\
\hline Satellite & 12 Sep 2005 & From 11:15 to 11:20 & \\
& Date & MODIS granule & Aerosol type \\
& & acquisition time (UTC) & \\
\hline 14 Mar 2004 & From 10:45 to 10:50 & \\
& 23 Apr 2004 & From 11:35 to 11:40 & \\
& 15 Jun 2004 & From 11:55 to 12:00 & \\
& 10 Aug 2004 & From 11:05 to 11:10 & \\
& 14 Aug 2004 & From 10:40 to 10:45 & \\
17 Sep 2004 & From 12:05 to 12:10 & Clean \\
12 Apr 2005 & From 11:25 to 11:30 & \\
18 May 2005 & From 11:00 to 11:05 & \\
15 Jun 2005 & From 11:25 to 11:30 & \\
3 Aug 2005 & From 12:05 to 12:10 & \\
19 Sep 2005 & From 11:20 to 11:25 & \\
\hline
\end{tabular}

within the error bars (standard deviation) of the MODIS derived surface spectral reflectance. As for Cabo da Roca area, some differences may arise since this is a coastline region, where the atmospheric correction may sometimes be problematic due to cloud and/or fog occurrences that may not be properly screened in the AERONET 1.5 level data used in the present study, introducing considerable errors in the aerosol inversions and radiative transfer calculations.

The surface spectral reflectance is determined in the area of Évora, for winter and summer periods in 2004 (Table 3 and Fig. 3a and b). In 2005, only the summer period is considered to derive the surface spectral reflectance (Table 3 and Fig. 3c). This is done in order to allow for the study of strong aerosol events that occurred in that period. Although it doesn't completely belong to that period, the September month is also included in the summer period since the surface spectral reflectance curve is approximately the same as the curves considered in the summer months. The winter season, for 2005, is not considered at the Évora site since on one hand, typically clean days (low aerosol loads in the atmosphere) were cloud contaminated over the areas of study and on the other hand, no significant aerosol events occurred during this season. For Cabo da Roca region, during year 2004, both winter and summer periods are considered as well (Table 4 and Fig. $4 a$ and b). In 2005, the periods considered are spring and summer, with the September month included in the summer period once again because the surface spectral reflectance curve for this month is very similar to the curves considered for the summer period (Table 4 and Fig. $4 \mathrm{c}$ and d).

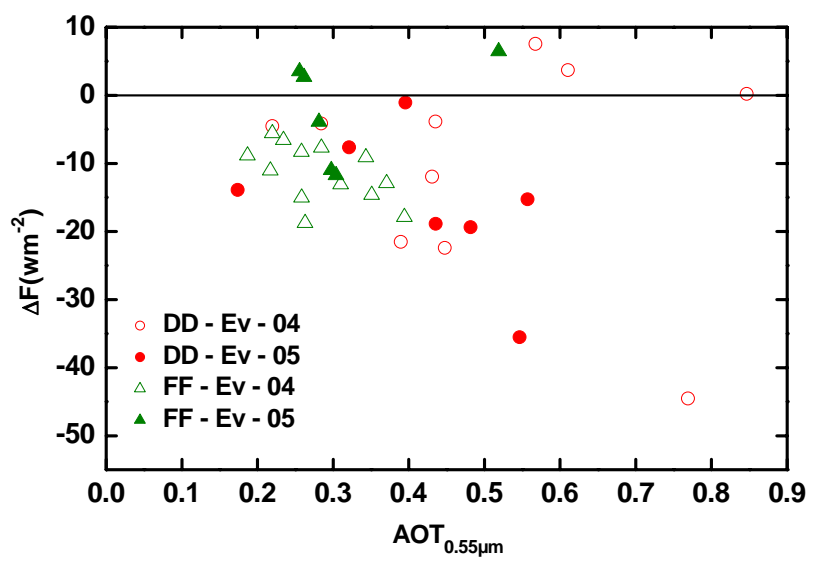

Fig. 5. Instantaneous TOA Direct Shortwave Aerosol Radiative Forcing (DSWARF $-\Delta F$ ) versus aerosol optical thickness at $0.55 \mu \mathrm{m}$, over Évora (Ev) during 2004 (open symbols) and 2005 (solid symbols), in the presence of Desert Dust (DD) and Forest Fires (FF) aerosol types.

The graphs of Figs. 3 to 4 show the spectral reflectance obtained, respectively for Évora and Cabo da Roca surrounding land areas. The graphs include the satellite derived surface reflectance values in the three spectral bands mentioned before $(0.434-0.448 \mu \mathrm{m}, 0.620-0.670 \mu \mathrm{m}$ and $0.841-$ $0.876 \mu \mathrm{m}$ ) (black circles), as well as the spectral reflectance curves taken from the database (grey line) and the best-fit curves (black line), obtained from the linear regression between the satellite derived surface spectral reflectance and the database spectral reflectance values, explained previously in Sect. 2.3. For Évora land area in 2004, the winter surface reflectance is based on the Aspen (name used according to the names in the database) curve (Fig. 3a) whereas for the two consecutive years (2004 and 2005) the summer surface reflectance is based on a dry grass curve (Fig. $3 \mathrm{~b}$ and c), both surface types present in the USGS database.

As it would be expected, the Évora land vegetation type in winter presents substantial differences from that in summer, as it can be observed in Fig. 3a and b, which shows the results obtained for Évora nearby rural area during winter and summer 2004.

For Évora land area (Fig. 3c), the curve obtained for the surface spectral reflectance during summer 2005, is based again on a dry grass curve (the same as summer 2004).

For Cabo da Roca land area, the surface reflectance is, for all seasons in 2004 and 2005, based on the Aspen_ynp spectral reflectance curve of the USGS database (Fig. 4).

An interesting feature of the spectral reflectance curves obtained for 2005 in Cabo da Roca (Fig. 4c and d), is that these values overestimate the database surface spectral reflectance values, whereas the same is not observed for 2004. This may be connected to the fact that 2005 was a very dry year in continental Portugal, with very few precipitation 
Table 3. Surface spectral reflectance obtained from the USGS database $\left(\rho_{S}\right)$ and spatial mean values $\left(\overline{\rho_{S}}\right)$ retrieved from satellite measurements for Évora region, years 2004 and 2005.

\begin{tabular}{cccccccccc}
\hline $\begin{array}{c}\text { Évora } \\
\begin{array}{c}\text { Wavelength } \\
(\mu \mathrm{m})\end{array}\end{array}$ & $\begin{array}{c}\rho_{S} \\
\text { database }\end{array}$ & $\begin{array}{c}\bar{\rho}_{S} \\
\text { MODIS }\end{array}$ & $\begin{array}{c}\text { Standard } \\
\text { deviation }\end{array}$ & $\begin{array}{c}\rho_{S} \\
\text { database }\end{array}$ & $\begin{array}{c}\overline{\rho_{s}} \\
\text { MODIS }\end{array}$ & $\begin{array}{c}\text { Standard } \\
\text { deviation }\end{array}$ & $\begin{array}{c}\rho_{S} \\
\text { database }\end{array}$ & $\begin{array}{c}\bar{\rho}_{s} \\
\text { MODIS }\end{array}$ & $\begin{array}{c}\text { Standard } \\
\text { deviation }\end{array}$ \\
\hline 0.440 & 0.056 & 0.024 & 0.002 & 0.080 & 0.070 & 0.017 & 0.080 & 0.070 & 0.009 \\
0.670 & 0.056 & 0.041 & 0.001 & 0.235 & 0.201 & 0.022 & 0.235 & 0.183 & 0.020 \\
0.870 & 0.475 & 0.455 & 0.003 & 0.316 & 0.298 & 0.033 & 0.316 & 0.309 & 0.035 \\
\hline
\end{tabular}

Table 4. The same as in Table 3 but for Cabo da Roca region, years 2004 (upper part) and 2005 (lower part).

\begin{tabular}{ccccccc}
\hline $\begin{array}{c}\text { Cabo da Roca } \\
\text { Wavelength } \\
(\mu \mathrm{m})\end{array}$ & $\begin{array}{c}\rho_{S} \\
\text { database }\end{array}$ & $\begin{array}{c}\overline{\rho_{s}} \\
\text { MODIS }\end{array}$ & $\begin{array}{c}\text { Standard } \\
\text { deviation }\end{array}$ & $\begin{array}{c}\rho_{s} \\
\text { database }\end{array}$ & $\begin{array}{c}\overline{\rho_{s}} \\
\text { MODIS }\end{array}$ & $\begin{array}{c}\text { Standard } \\
\text { deviation }\end{array}$ \\
\hline 0.440 & 0.024 & 0.052 & $4.407 \mathrm{E}-4$ & 0.024 & 0.058 & 0.019 \\
0.670 & 0.030 & 0.057 & 0.004 & 0.030 & 0.063 & 0.020 \\
0.870 & 0.321 & 0.306 & 0.056 & 0.321 & 0.317 & 0.013 \\
\hline Cabo da Roca & \multicolumn{3}{c}{ Spring 2005} & & & Summer 2005 \\
Wavelength & $\rho_{S}$ & $\overline{\rho_{s}}$ & Standard & $\rho_{s}$ & $\overline{\rho_{s}}$ & Standard \\
$(\mu \mathrm{m})$ & database & MODIS & deviation & database & MODIS & deviation \\
\hline 0.440 & 0.024 & 0.057 & 0.010 & 0.024 & 0.050 & 0.025 \\
0.670 & 0.030 & 0.060 & 0.008 & 0.030 & 0.051 & 0.011 \\
0.870 & 0.321 & 0.334 & 0.020 & 0.321 & 0.33 & 0.036 \\
\hline
\end{tabular}

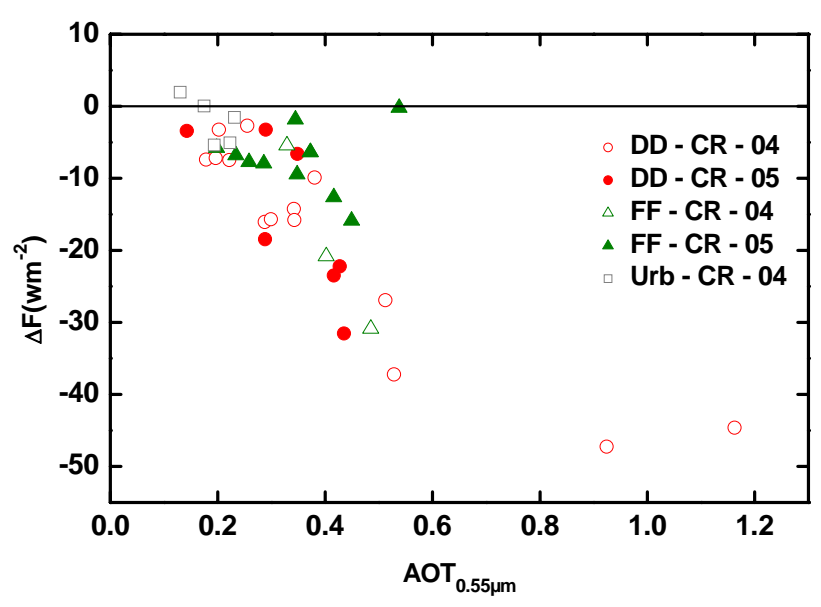

Fig. 6. Same as in Fig. 5 but for Cabo da Roca (CR) land area considering also the presence of Urban (Urb) aerosol type.

occurrences, classified as severe and extreme drought from January until September 2005. Therefore, the vegetation suffered a change related to the increase of the surface spectral reflectance, which was not taken into consideration in this case, since the same database spectral reflectance val- ues were considered both for 2004 and 2005 (Aspen type). This is notable for the Cabo da Roca site, where precipitation plays a core role in the surface vegetation characteristics. Évora site is characterized by semi-arid surfaces, which leads to a lower impact of droughts in terms of changes in the surface spectral reflectance, in the summer season.

\subsection{Assessment of the radiative forcing for different aerosol type events}

The instantaneous TOA Direct Shortwave Aerosol Radiative Forcing (DSWARF) is calculated as described in Sect. 2.4. The major aerosol events that occurred in the regions of study were Forest Fires (FF) and Desert Dust (DD). However, the analysis of air mass backward trajectories, as well as the aerosol type classification criteria of Table 1, allowed for considering also the urban/industrial (Urb) aerosol type for Cabo da Roca area, in 2004.

The results obtained for Évora land area (Fig. 5) during years 2004 and 2005, show that negative TOA DSWARF values are found in the majority of the cases, nevertheless three positive TOA DSWARF values are found for the Desert Dust aerosol and another three cases for the Forest Fire aerosol type. 


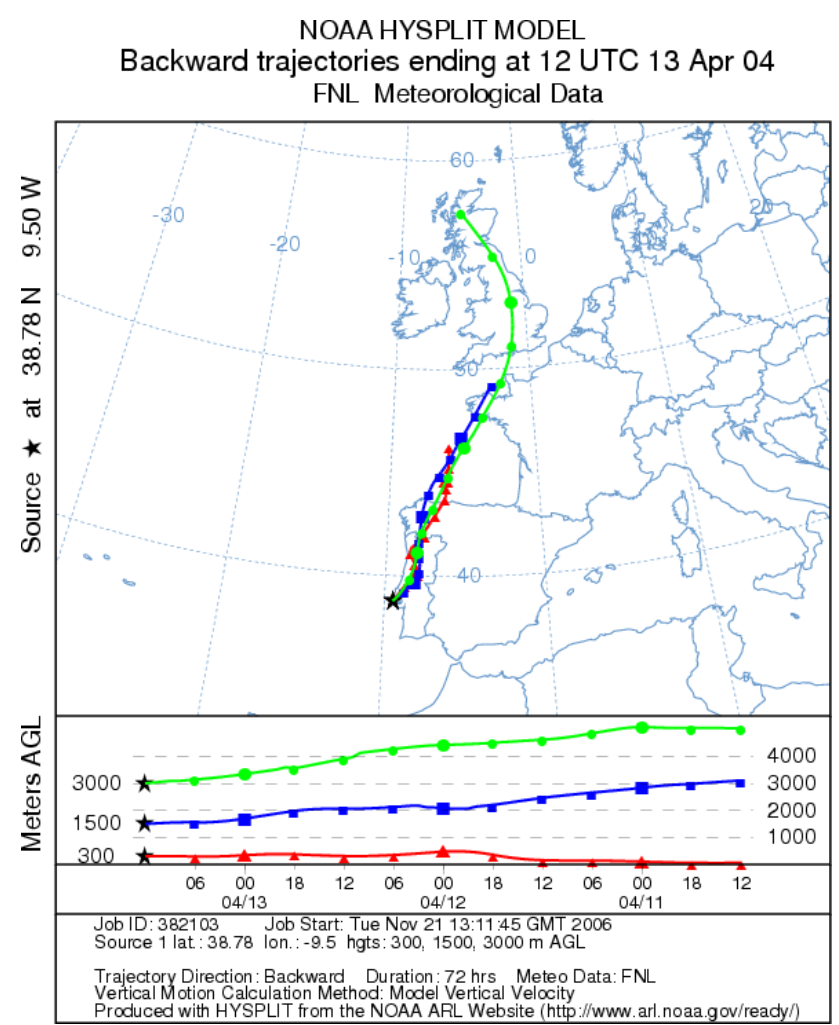

(a)

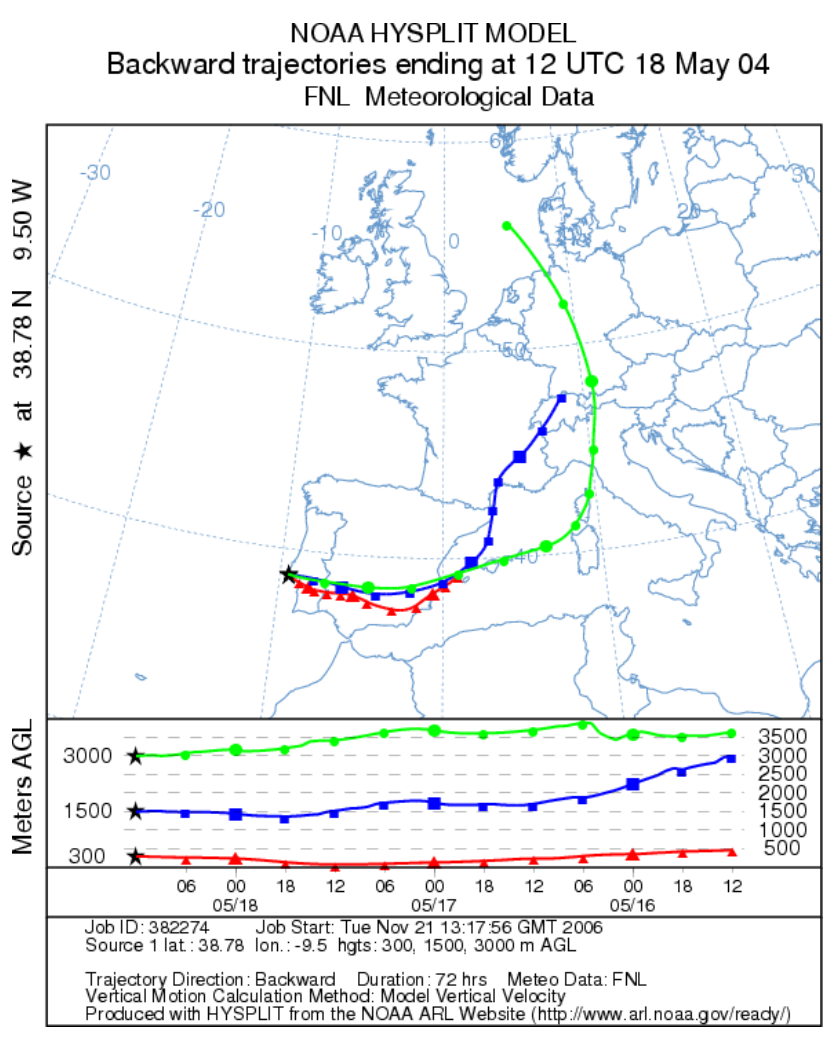

(b)

Fig. 7. Air mass backward trajectories ending over Cabo da Roca region on 13 April (a) and 18 May 2004 (b).

As for Cabo da Roca land area, results are shown in the graph of Fig. 6 during the same years for the Forest Fire, Desert Dust and urban/industrial aerosol types, the latter being considered only for year 2004. To note that, negative TOA DSWARF values are always found for Desert Dust and Forest Fire aerosol types, thus contributing to a cooling effect at the TOA over Cabo da Roca land area. For urban/industrial aerosol type, both positive and negative TOA DSWARF values are found, although these values are very close to zero.

The different TOA DSWARF values found for the same site and for the same aerosol type may be associated with the presence of aerosols in the atmosphere with different scattering/absorbing capabilities (Haywood and Shine, 1995; Hansen et al., 1997; Russel et al., 2002; Elias et al., 2004; Costa, 2004; and Costa et al., 2006). Pure scattering aerosol particles induce a cooling effect, whereas absorbing aerosols lead to a warming effect (Satheesh, 2002). The magnitude of the single scattering albedo (SSA) can be considered as an index for the relative dominance of the scattering process with respect to absorption. Therefore, the knowledge of the SSA is crucial and even a small change in its estimation can flip the sign of TOA DSWARF as observed and in agreement with other authors (Takemura et al., 2002).
In order to understand the different SSA values found for aerosols over Évora and over Cabo da Roca, the 72-h air mass back-trajectories at several altitudes (between 200 to $3000 \mathrm{~m}$ a.g.1.), ending in Évora and Cabo da Roca are also calculated using the HYSPLIT model (see Sect. 2.2).

Another consideration that has to be made is the effect of the underlying surface by which the aerosol forcing may change sign from negative (cooling) to positive (warming) when the surface reflection is high (Liao et al., 1998; Satheesh, 2002). When aerosols are present over a land surface with high reflection, their impact on solar radiation is very significant, because the radiation reflected from the surface below would interact again with the aerosols present above.

Hence, the next three subsections explore three different situations found in this study, which illustrate the above considerations. According to Eq. (5) the Surface forcing is estimated for these three different situations.

A discussion on the estimated TOA forcing efficiency is made in the last subsection. 


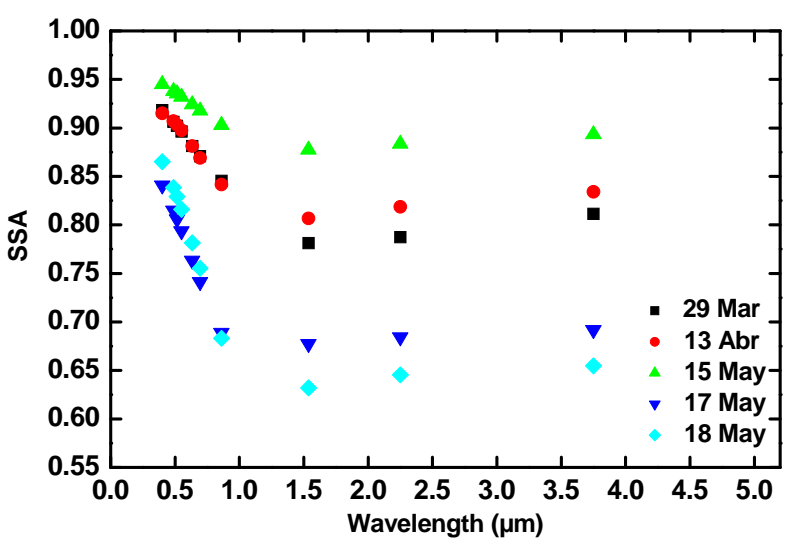

Fig. 8. Spectral aerosol single scattering albedo over Cabo da Roca land area, in the presence of urban/industrial aerosols in Spring 2004.

\subsubsection{Effect of aerosol absorption - urban/industrial} aerosols

Considering the urban/industrial events occurred in Cabo da Roca land area in 2004, different signs of the TOA DSWARF values are found, although results are obtained for the same region (same surface spectral reflectance is used). This may be explained through the analysis of the 72-h air mass backtrajectory calculations at 300, 1500 and $3000 \mathrm{~m}$ a.g.l., ending at Cabo da Roca region, corresponding to the two different situations (Fig. 7). The different signs of the TOA DSWARF are connected to the differences in the SSA values shown in Fig. 8. On 29 March, 13 April, 15 and 24 May, the obtained TOA DSWARF values, normalized to the aerosol optical thickness at $550 \mathrm{~nm}\left(\Delta F_{e}-\right.$ Sect. 2.4), have a negative sign, whereas on 17 and 18 May, the TOA DSWARF values are positive (see upper panel of Fig. 11a). Based on the 72-h air mass back-trajectories, ending over Cabo da Roca region, it is possible to observe that for those days the TOA DSWARF have a negative sign (e.g. 13 April), the urban and industrial pollution particles travel from the North of Europe to the Atlantic ocean and penetrate into the Iberian Peninsula from the North before reaching Cabo da Roca region (left graph of Fig. 7 as an example). On 17 and 18 May, when positive TOA DSWARF values are found, the urban and industrial particles travel from central Europe, pass the Mediterranean Sea and penetrate into the Iberian Peninsula coming from East (right graph of Fig. 7 only for 18 May) before reaching Cabo da Roca region. When the aerosol arrives over Cabo da Roca region, it is constituted by a mixture of pollution, maritime and continental aerosol types. These different paths followed by the aerosol particles and the different initial sources may explain the different SSA values obtained and shown in Fig. 8 for all above mentioned days. Moreover, the analysis of Fig. 8 shows that the urban/industrial aerosol particles for 17 and 18 May (positive
TOA DSWARF values - upper panel of Fig. 11a, have accordingly, lower SSA values, hence more absorbing than the urban/industrial aerosol particles found on the other days of the study. To note that these aerosols coming from North Europe, pass over the Atlantic Ocean, and mix with the more scattering Sea Salt aerosols, being then less absorbing. For the days presenting higher SSA values, namely 29 March, 13 April, 15 and 24 May, the TOA DSWARF values are, accordingly, negative (upper panel of Fig. 11a).

According to the upper panels of Fig. 11a and b, and comparing the TOA and the surface radiative forcing efficiencies for 2004, a positive aerosol atmospheric radiative forcing is found for all the Urban events over Cabo da Roca site, meaning that in all these situations (these type of aerosols) the atmosphere is heated and consequently its dynamics affected.

\subsubsection{Effect of aerosol absorption - aged smoke aerosols}

The different TOA DSWARF signs as well the correspondent Surface DSWARF signs (or DSWARF of the entire atmosphere, through Eq. 6) found for the Forest Fires aerosols reaching Évora are studied through the examination of the 72-h air mass back-trajectories at 200, 1400 and $2900 \mathrm{~m}$ a.g.l., ending at Évora (Fig. 9), as well as of the SSA values obtained for Évora region as shown in Fig. 10. From the AERONET aerosol optical thickness values obtained for Évora, (and aerosol type classification presented in Table 1), as well as from the analysis of the back-trajectories of Fig. 9, it can be noted that, although the aerosol particles belong to the same type (Forest Fire), they originate in different regions.

For 17, 18, 19 June and 10 July 2005, no information concerning fire occurrences was available, nevertheless the AERONET aerosol optical thickness values obtained for Évora and the aerosol type classification presented in Table 1, allowed to consider the "Forest Fire" aerosol type. The backtrajectory calculations, shown on the left graph of Fig. 9 for 19 June, evidence that the aerosol particles coming to Évora at the lower levels are originated in central Spain, probably contaminated by the Forest Fires that were affecting those regions. The fires, in these cases, produced aerosols that are measured in Évora as being less absorbing (higher SSA as shown in Fig. 10) than the forest fire aerosols also measured in Évora that originated closer and travelled from different paths, shown on the right graph of Fig. 9 (see below), in correspondence with the negative radiative forcings obtained at the top of the atmosphere as well as at the surface, shown respectively in the lower panels of Fig. 11a and b for 2005.

According to the Portuguese Forest Fires Annual Report (DGRF, 2006), several Forest Fire events started on $14 \mathrm{Au}-$ gust 2005 on the north and central regions of continental Portugal, burning an extensive area and lasting a few days. These particles reached Évora region (right graph of Fig. 9) and present lower spectral SSA (more absorbing) for 15, 16 and 20 August 2005, as shown in Fig. 10, than the particles 


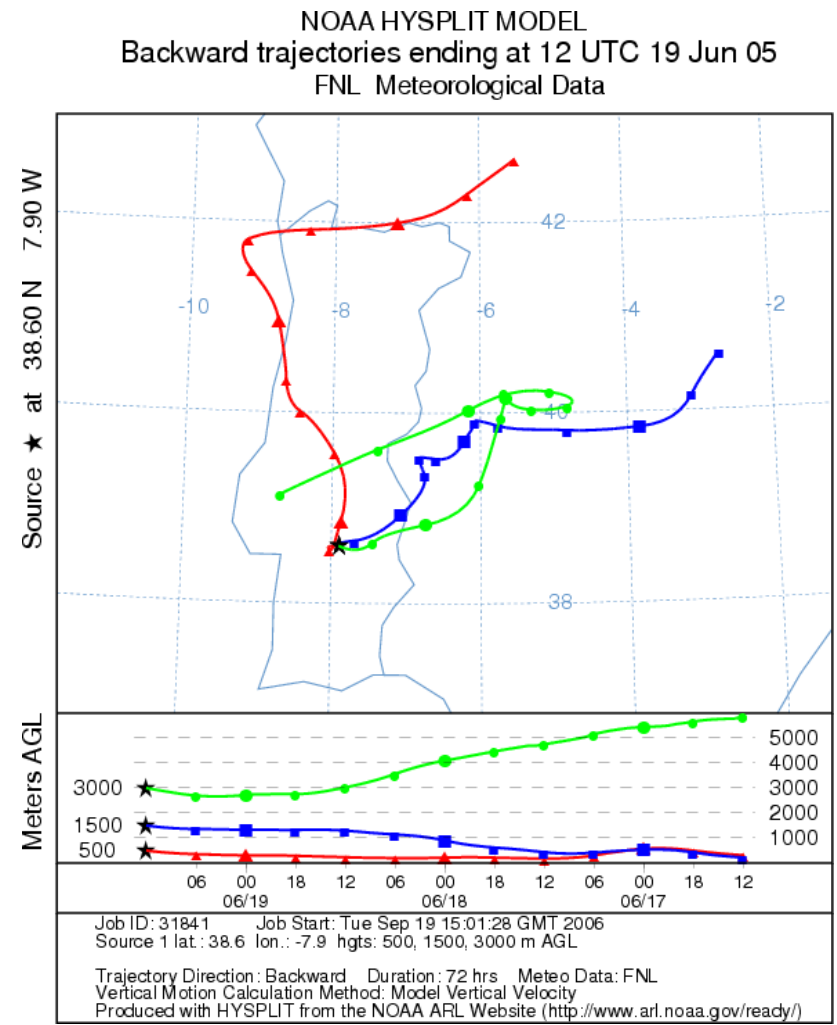

(a)
NOAA HYSPLIT MODEL

Backward trajectories ending at 12 UTC 16 Aug 05

FNL Meteorological Data

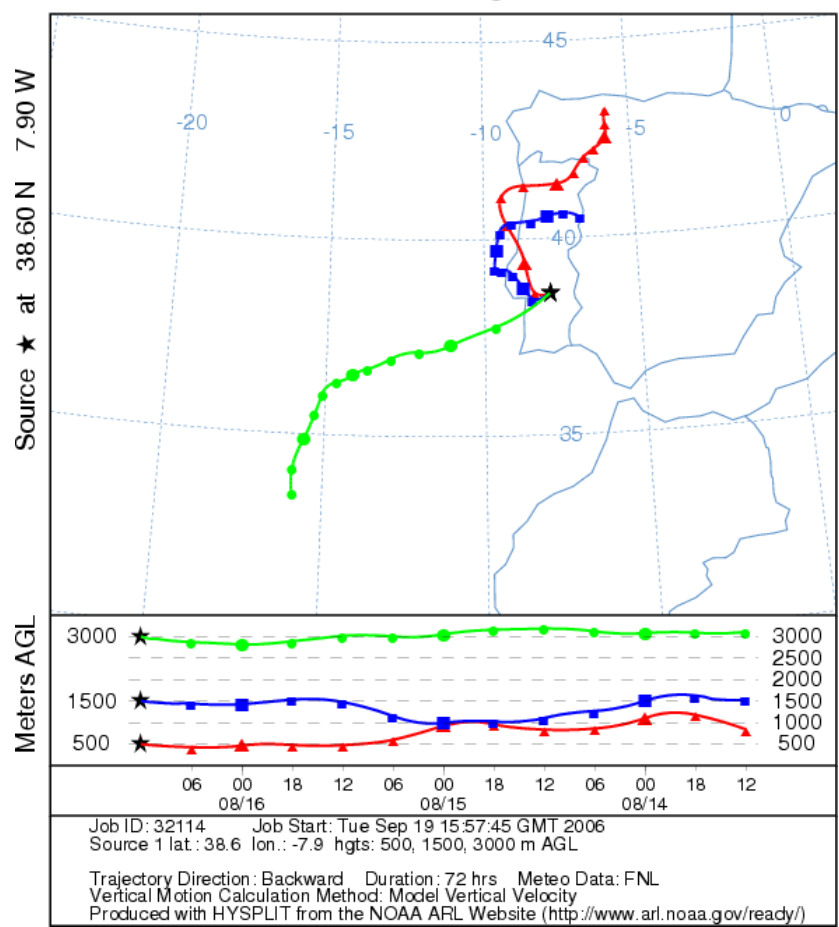

(b)

Fig. 9. Air mass backward trajectories ending over Évora region on 19 June (a) and 16 August 2005 (b).

travelling longer distances, which is the case of the fires occurring during June-July 2005 in Spain. The forest fire aerosols originated in Portugal in 2005, being more absorbing cause the positive radiative forcing values at the top of the atmosphere (lower panel of Fig. 11a), and a stronger positive radiative forcing of the entire atmosphere, therefore a negative radiative forcing at the surface, as shown in the lower panel of Fig. 11b. It is well known that the travel time of these aerosols is related to the ratio between elementary carbon and organic compounds (EC/OC) content, therefore interfering with their absorption properties (Reid et al., 1998; Andreae and Merlet, 2001; Eck et al., 2001). On the other hand, different types of "burned" vegetation may cause different aerosol properties (Ramos, 2006), which could also explain the different aerosol single scattering albedo values and the corresponding TOA and Surface DSWARF signs. Nevertheless, it is not expected that the vegetation types in the Iberian Peninsula differ that much, therefore the smoke from the forest fires suffered, most probably, an aging process when travelling from Spain to Portugal, becoming less absorbing than the ones generated in Portugal, originating negative DSWARF values both at TOA and at the surface.

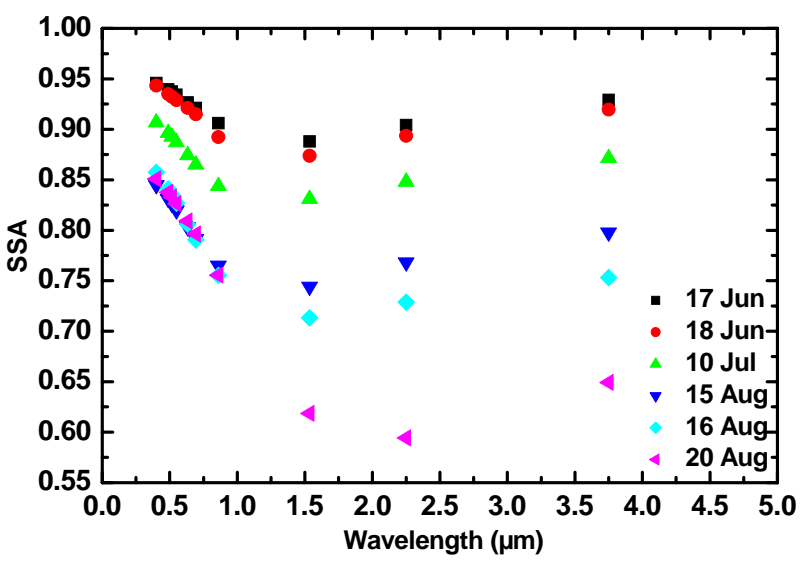

Fig. 10. Spectral aerosol single scattering albedo over Évora land area, in the presence of Forest Fire aerosol events during Spring and Summer 2005.

3.2.3 Effect of desert dust absorption and of the underlying surface

The TOA DSWARF values normalized to the aerosol optical thickness at $550 \mathrm{~nm}\left(\Delta F_{e}-\right.$ Sect. 2.4), for a strong Desert 

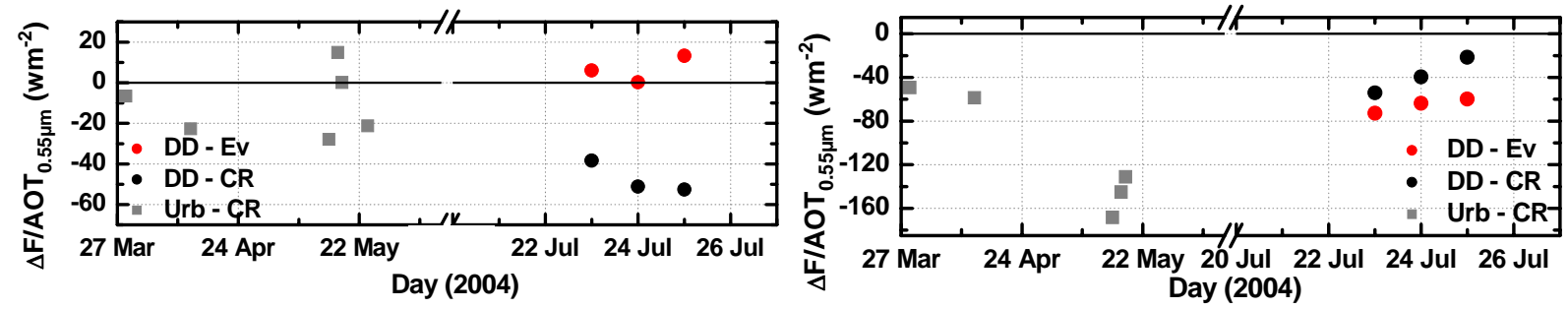

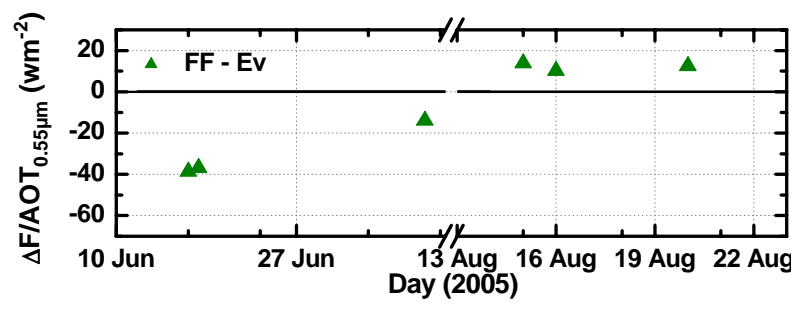

(a)

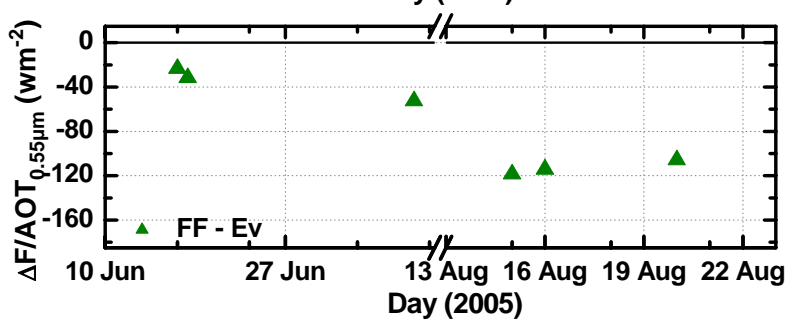

(b)

Fig. 11. Instantaneous TOA (a) and Surface (b) DSWARF values normalized to the AOT at $0.55 \mu \mathrm{m}$, for selected days, over Évora (Ev) and Cabo da Roca (CR) land areas, for the desert dust (DD) and urban/industrial (Urb) during 2004 - (upper panels) and forest fire (FF) during 2005 - (lower panels) aerosol types.

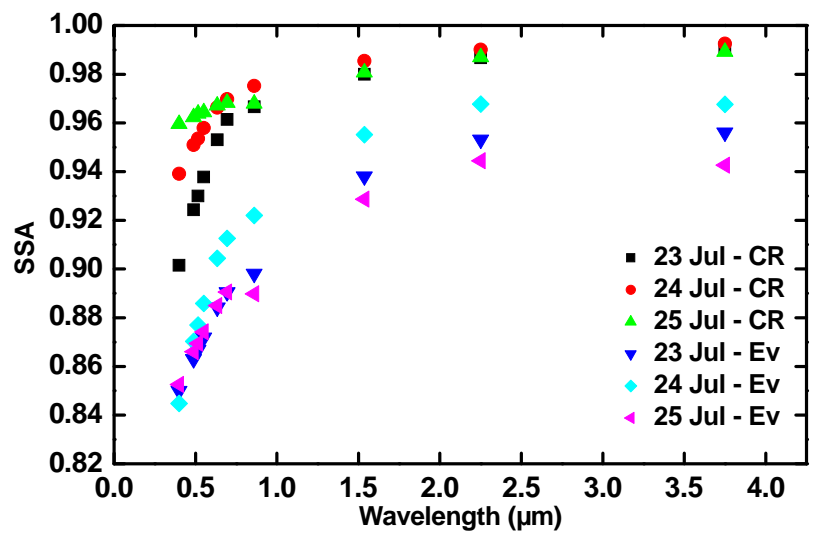

Fig. 12. Spectral aerosol single scattering albedo over Évora (Ev) and Cabo da Roca (CR) regions, for a Desert Dust event on 23, 24 and 25 July 2004.

Dust aerosol event that occurred from 23 to 25 July 2004, are shown in the upper panel of Fig. 11a. The comparisons of the instantaneous TOA DSWARF results obtained, due to this strong Desert Dust aerosol event, for Évora and Cabo da Roca land areas, show that opposite signs are observed: while over Évora the TOA DSWARF is slightly positive, a large negative value is obtained over Cabo da Roca.

As explained before, these different TOA DSWARF values may be associated with the effect of the underlying surface and with the aerosol absorbing potential. Based on the right graph of Figs. 3 and 4 (corresponding to the summer period) and on Tables 3 and 4, it can be observed that the surface spectral reflectance in Évora is higher than in Cabo da Roca (for example, in Évora $\bar{\rho}_{s, \lambda=0.67}=0.20$ and for Cabo da Roca

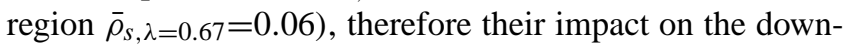
welling solar irradiance is quite different (Elias and Silva, 2004).

The graph of Fig. 12 shows the SSA values obtained as a function of wavelength, for the Desert Dust aerosols of the above mentioned episode reaching Évora and Cabo da Roca. We note that although the spectral behaviours are very similar, the aerosols in Évora area have lower SSA values than aerosols in Cabo da Roca area, thus leading to a warming instead of a cooling effect at the TOA.

From the 72-h air mass back-trajectories at 200, 1400 and 2900 m a.g.l., ending in Évora (Fig. 13), it can be observed that the desert dust leaving the western African coast travel to the Atlantic ocean and penetrate in Europe passing over Cabo da Roca before reaching Évora. As Cabo da Roca is located in the vicinity of Lisbon and suffers the influence of the urban and industrial pollution from this city, as well as from the industrial surrounding region, Desert Dust aerosols may have mixed with the urban/industrial aerosols already present in the region. The scattering aerosols coming from the Sahara Desert and reaching Cabo da Roca become more absorbing as they mix with urban/industrial aerosols over the Greater Lisbon area and penetrate into the Continent, about $150 \mathrm{~km}$, to arrive over Évora.

Thus in this case, apparently both the surface reflectance and the aerosol absorption effects reflect in higher TOA DSWARF in Évora than in Cabo da Roca, where negative values are obtained, leading to a cooling effect at the TOA.

As for the atmospheric radiative forcing and according to the upper panels of Fig. 11a and b, a positive atmospheric 


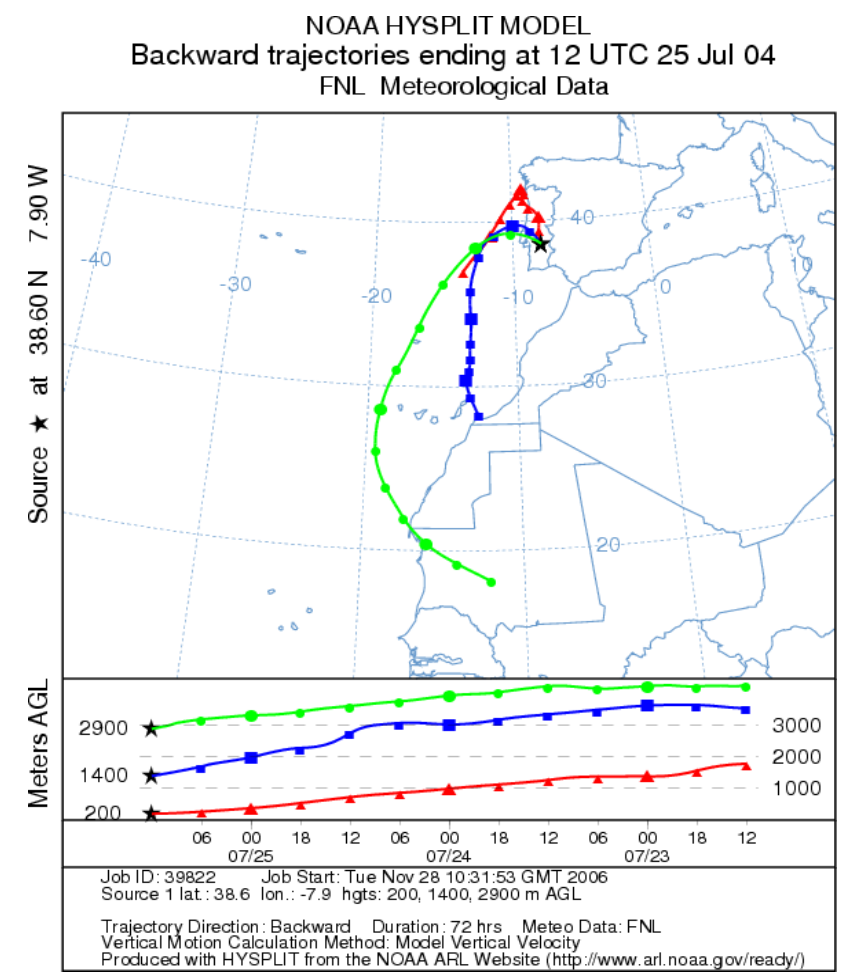

Fig. 13. Air mass backward trajectories ending over Évora region on 25 July 2004.

radiative forcing is found for the period 23-25 July 2004, over Évora region, therefore leading to the atmospheric heating. For Cabo da Roca region, on the first day (23 July 2004) a positive value of atmospheric radiative forcing is also obtained, whereas for the following days negative atmospheric radiative forcing values are found (atmospheric cooling). These differences can be, once again, verified by the single scattering albedo values (Fig. 12), which exhibit, on the first day of the desert dust event, 23 July, lower values (more absorbing) than the corresponding SSA values for the following days (24 and 25 July), suggesting that the mixture with the urban/industrial aerosols from the Greater Lisbon area, only occurred in the first day of the event giving rise to the predominance of scattering desert dust aerosols on the following days. The consequence of the different atmospheric radiative forcing over an horizontal distance of about $150 \mathrm{~km}$, may enhance the atmospheric temperature gradient and the associated atmospheric dynamics.

\subsubsection{Forcing efficiency at the TOA}

Figures 14 and 15 also show the relation between the AOT at $0.55 \mu \mathrm{m}$ and the TOA DSWARF values, where the slopes of the linear fittings can be interpreted as the average forcing efficiencies $\left(\Delta F_{e}-\right.$ Sect. 2.4) respectively in Évora and Cabo da Roca land areas, in the presence of Desert Dust and Forest Fire aerosols, during 2004 and 2005. For Desert

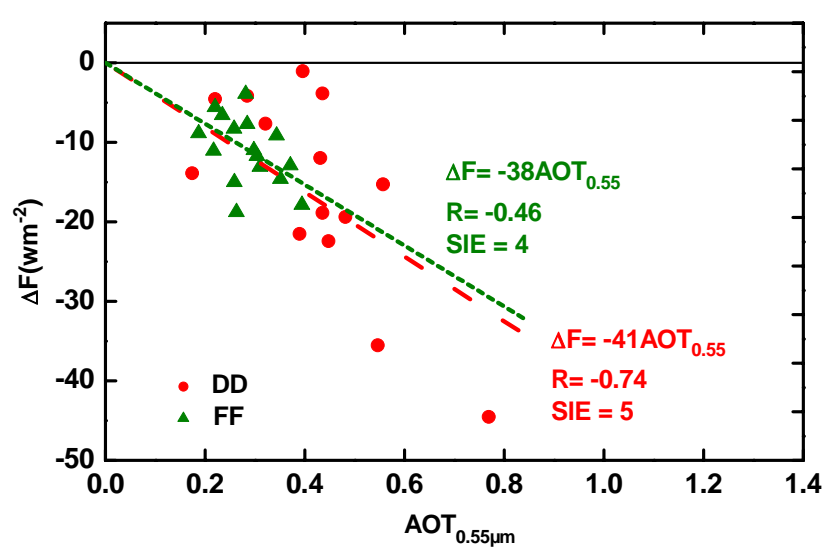

Fig. 14. Instantaneous TOA DSWARF versus aerosol optical thickness at $0.55 \mu \mathrm{m}$, during 2004 and 2005 over Évora land area, in the presence of Desert Dust (DD) and Forest Fire (FF) aerosol types. $R$ is the correlation coefficient and SIE is the slope error of the linear fits.

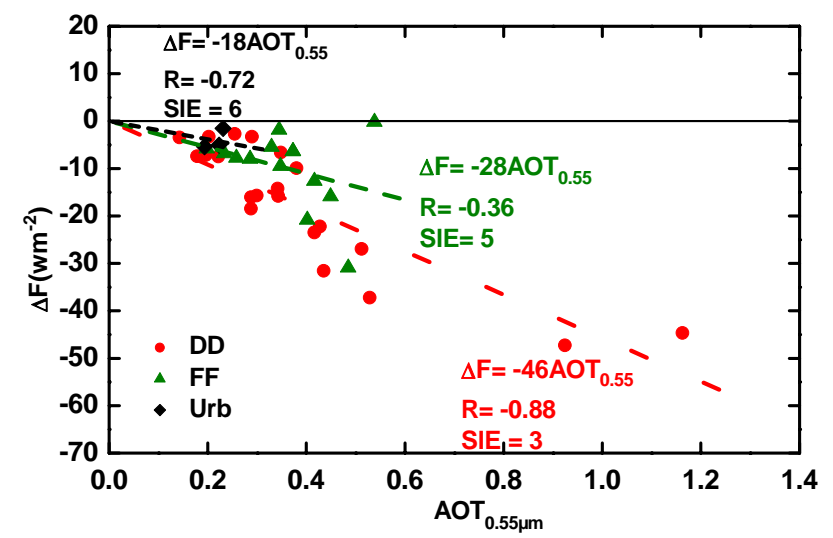

Fig. 15. Same as in Fig. 14 but for Cabo da Roca land area.

Dust aerosols, over Évora land region (considering only the TOA DSWARF negative values), the forcing efficiency is estimated to be $-41 \mathrm{Wm}^{-2} / \mathrm{AOT}_{0.55}$ (Fig. 14) whereas for Cabo da Roca area the forcing efficiency is estimated to be $-46 \mathrm{Wm}^{-2} / \mathrm{AOT}_{0.55}$ (Fig. 15) for the overall studied cases (Fig. 6), with the absolute correlation coefficient $(R)$ values of 0.74 and 0.88 , respectively.

According to Lyamani et al. (2006), under a strong desert dust event over Spain, the value estimated for daily averaged TOA radiative forcing efficiency was $-14.5 \mathrm{Wm}^{-2} / \mathrm{AOT}_{0.67}$. For Évora region (were a similar surface cover can be considered) the daily averaged TOA radiative forcing efficiency, due to Desert Dust aerosols, is estimated to be $-18 \mathrm{Wm}^{-2} / \mathrm{AOT}_{0.55}$. Though the values of the forcing efficiencies are comparable, one has to be aware that, the radiative forcings are calculated at different spectral regions by Lyamani $(0.4-0.7 \mu \mathrm{m})$ and by us $(0.25-4 \mu \mathrm{m})$; for Évora region the daily averaged TOA radiative forcing efficiency 
is estimated assuming that the TOA radiative forcing values have a constant value through the diurnal part of the day, which is not the case of Lyamani's situation.

The forcing efficiency due to the Desert Dust aerosol type (considering all TOA DSWARF values), is more pronounced for Cabo da Roca $\left(-46 \mathrm{Wm}^{-2} / \mathrm{AOT}_{0.55}\right)$, the Atlantic Ocean west coast site, than for Évora $\left(-25 \mathrm{Wm}^{-2} / \mathrm{AOT}_{0.55}\right)$, the inland site.

In the presence of Forest Fire aerosols, over Cabo da Roca region for the same two years, the forcing efficiency is estimated to be $-28 \mathrm{Wm}^{-2} / \mathrm{AOT}_{0.55}$ for the overall studied cases (Fig. 6) with an absolute correlation coefficient value of 0.36 (Fig. 15). In Évora nearby rural area considering only the DSWARF negative values a forcing efficiency of $-38 \mathrm{Wm}^{-2} / \mathrm{AOT}_{0.55}$ is found $(R=0.46)$, which is in agreement with the value found by Christopher et al. (1999), who has estimated a forcing efficiency of $-43 \mathrm{Wm}^{-2} / \mathrm{AOT}_{0.55}$ due to Forest Fire aerosols over a grass land surface (comparable to the surface around Évora). When urban/industrial aerosol type is considered over Cabo da Roca area, the forcing efficiency is estimated to be $-18 \mathrm{Wm}^{-2} / \mathrm{AOT}_{0.55}$, with an absolute correlation coefficient value of 0.72 , but with a very low number of data points, which is not statistically significant. Further investigation is foreseen for this aerosol type in order to better assess its radiative effects.

\section{Summary and conclusions}

The main objective of this work was the assessment of the aerosol radiative forcing at the TOA in two regions of continental Portugal, Évora and Cabo da Roca, with different surface reflectance properties and reached by different aerosol type events. A method to estimate the direct SW aerosol radiative forcing at the TOA was developed and applied to several aerosol situations. An intermediary objective of this work was the retrieval of the surface spectral reflectance for these selected regions from satellite spectral measurements.

The methodology developed to retrieve the surface spectral reflectance was considered adequate since the satellite retrievals obtained fit well to the spectral reflectance curves obtained from the USGS database, allowing deriving the SW surface spectral reflectance for Évora and Cabo da Roca land regions.

This work shows that the surface spectral reflectance as well as the aerosol single scattering albedo are very important parameters for determining the direct radiative forcing at the top of the atmosphere, and that Desert Dust and Forest Fire aerosols play an important role in the radiation budget, at a local/regional scale. In the majority of the cases, the aerosol radiative forcing values obtained are negative, indicating a tendency for cooling the Earth.

The TOA forcing efficiency estimated is negative in most of the cases, indicating a cooling effect at the TOA. For the Desert Dust aerosol type the efficiency is more pronounced for Cabo da Roca $\left(-46 \mathrm{Wm}^{-2} / \mathrm{AOT}_{0.55}\right.$ ), the Atlantic Ocean west coast site, than for Évora $\left(-25 \mathrm{Wm}^{-2} / \mathrm{AOT}_{0.55}\right)$, the inland site. This large difference is related to the fact that occasionally Desert Dust aerosols penetrate in Europe through Cabo da Roca and on their way towards inland regions, they mix with pollution from Lisbon and surrounding industrial regions (urban/industrial aerosols), thus becoming more absorbing. This effect is also observed in the surface forcing efficiency where in turn lower values are found in Évora, $\left(-66 \mathrm{Wm}^{-2} / \mathrm{AOT}_{0.55}\right)$, than in Cabo da Roca $\left(-38 \mathrm{Wm}^{-2} / \mathrm{AOT}_{0.55}\right)$ for the considered specific situations. The fact that at the TOA the forcing efficiency is more pronounced for Cabo da Roca and at the surface the opposite is observed, is inherent to the definitions (Eqs. 4 and 5). Consequently, over Évora region, the atmospheric radiative forcing of the entire atmosphere indicates a warming of the atmosphere due to absorbing aerosols, as it would be expected. Whenever the mixing process between different aerosol types decreases and desert dust aerosols predominate, an atmospheric temperature gradient can be established over two different sites (Cabo da Roca and Évora) due to the different signs of the atmospheric radiative forcing over these regions, with impact on the atmospheric dynamics.

On the other hand, also the different surface types characterizing both sites (higher surface spectral reflectance in Évora region) play an important part in the TOA forcing. Both effects probably combine and give origin to higher TOA DSWARF values in Évora than in Cabo da Roca, sometimes even positive.

As for the forest fire aerosols reaching Évora region and for the specific situations considered, the TOA and surface DSWARF average values are both negative $\left(-30 \mathrm{Wm}^{-2} / \mathrm{AOT}_{0.55}\right.$ at the TOA and $-36 \mathrm{Wm}^{-2} / \mathrm{AOT}_{0.55}$ at the surface) due to less absorbing forest fire aerosols, coming from longer distances suffering a rapid aging process; for forest fire aerosols coming only from shorter distances, with stronger absorbing characteristics (lower single scattering albedo), the TOA and the surface DSWARF average values present opposite signs $\left(12 \mathrm{Wm}^{-2} / \mathrm{AOT}_{0.55}\right.$ at the TOA and $-113 \mathrm{Wm}^{-2} / \mathrm{AOT}_{0.55}$ at the surface), meaning a very pronounced atmospheric heating, as expected.

Acknowledgements. The work was funded by the Portuguese FCT through projects POCI/CTE-ATM/59773/2004 and PDCTE/CTA/49826/2003. The first author is supported by FCT through grant SFRH/BD/27870/2006.

The data used in this study were acquired as part of the NASA's Earth Science Enterprise. The algorithms were developed by the MODIS Science Teams. The data were processed by the MODIS Adaptive Processing System (MODAPS) and Goddard Distributed Active Archive Center (DAAC), and are archived and distributed by the Goddard DAAC. We also thank the AERONET investigators and their staff for establishing and maintaining the sites used in this investigation.

The authors gratefully acknowledge the NOAA Air Resources Laboratory (ARL) for the provision of the HYSPLIT 
transport and dispersion model and/or READY website (http://www.arl.noaa.gov/ready.html) used in this publication.

Edited by: G. Roberts

\section{References}

Andreae, M. and Merlet, P.: Emission of trace gases and aerosols from biomass burning, Global Biogeochem. Cy., 15, 955-966, 2001.

Barnes, W. L., Pagano, T. S., and Salomonson, V. V.: Prelaunch characteristics of the MODerate Resolution Imaging Spectroradiometer (MODIS) on EOS-AM1, IEEE T. Geosci. Remote, 36, 1088-1100, 1998.

Christopher, S. A., Li, X., Welch, R. M., Reid, J. S., Hobbs, P. V., Eck, T. F., and Holben, B.: Estimation of Surface and Top-ofAtmosphere Shortwave Irradiance in Biomass-Burning Regions during SCAR-B, J. Appl. Meteorol., 39, 1742-1753, 1999

Costa, M. J.: Aerosol and cloud satellite remote sensing: monitoring and modelling using passive sensors, Ph.D. Thesis, Department of Physics, University of Évora, Portugal, 233 pp., 2004.

Costa, M. J., Silva, A. M., and Levizzani, V.: Aerosol Characterization and Direct Radiative Forcing Assessment over the Ocean Part I: Methodology and sensitivity analysis, J. Appl. Meteorol., 43, 1799-1817, 2004.

Costa, M. J., Sohn, B. J., Levizzani, V., and Silva, A. M.: Radiative forcing of Asian dust determined from the synergized GOME and GMS satellite data - a case study, J. Meteorol. Soc. Jpn., 84(1), 85-95, 2006.

Direcção Geral dos Recursos Florestais - DGRF, Divisão de Defesa da Floresta contra incêndios: Incêndios Florestais Relatório de 2005, 26 pp., 2006.

Draxler, R. R. and Hess, G. D.: An overview of the Hysplit_4 modelling system for trajectories, Aust. Meteorol. Mag., 47, 295308, 1998.

Draxler, R. R. and Rolph, G. D.: HYSPLIT (HYbrid SingleParticle Lagrangian Integrated Trajectory) Model, NOAA Air Resources Laboratory, Silver Spring, MD, USA, available at: http://www.arl.noaa.gov/ready/hysplit4.html (last access: February 2007), 2003.

Dubovik, O. and King, M.: A flexible inversion algorithm for retrieval of aerosol optical properties from Sun and sky radiance measurements, J. Geophys. Res., 105, 20 673-20 696, 2000.

Dubovik, O., Smirnov, A., Holben, B. N., King, M., Kaufman, Y. J., Eck, T. F., and Slutsker, I.: Accuracy assessment of aerosol optical properties retrieval from AERONET Sun and sky radiance measurements, J. Geophys. Res., 105, 9791-9806, 2000.

Dubovik, O., Holben, B. N., Eck, T. F., Smirnov, A., Kaufman, Y. J., King, M., Tanré, D., and Slutsker, I.: Variability of absorption and optical properties of key aerosol types observed in worldwide locations, J. Atmos. Sci., 59, 590-608, 2002.

Eck, T. F., Holben, B., Sluster, I., and Setzer, A.: Characterization of the optical properties of biomass burning aerosols in Zambia during the 1997 ZIBBEE field campaign, J. Geophys. Res., 106, 3425-3448, 2001.

Elias, T. and Silva, A. M.: Correction of the ground-based measurements of radiance by the surface contribution for a better estimate of the aerosol radiative forcing, SPIE Proceedings, 5235, 149-159, 2004.
Elias, T., Silva, A. M., Figueira, M. J., Belo, N., Pereira, S., Formenti, P., and Helas, G.: Aerosol extinction and absorption in Évora, Portugal, during the European 2003 summer heat wave. Remote Sensing of Clouds and the Atmosphere IX, edited by: Schäfer, K. P., Comerón, A., Carleer, M. R., Picard, R. H., and Sifakis, N. I., SPIE Proceedings, 5571, 270-281, 2004.

Elias, T., Silva, A. M., Belo, N., Pereira, S., Formenti, P., Helas, G., and Wagner, F.: Aerosol extinction in a remote continental region of the Iberian Peninsula during summer, J. Geophys. Res., 111, D14204, doi:10.1029/2005JD006610, 2006.

Hansen, J. E., Sato, M., and Ruedy, R.: Radiative forcing and climate response, J. Geophys. Res., 102, 6831-6864, 1997.

Haywood, J. P. and Shine, K. P.: The effect of anthropogenic sulfate and soot aerosols on clear sky planetary radiation budget, Geophys. Res. Lett., 22, 603-606, 1995.

Haywood, J. and Boucher, O.: estimates of the direct and indirect radiative forcing due to tropospheric aerosols: a review, Rev. Geophys., 38, 513-543, 2000.

Holben, B., Eck, T. F., Slutsker, I., Tanre, D., Buis, J. P., Setzer, A., Vermote, E., Reagan, J. A., Kaufman, Y., Nakajima, T., Lavenu, F., Jankowiak, I., and Smirnov, A.: AERONET-A federated instrument network and data archived for aerosol characterization, Remote Sens. Environ., 66, 1-16, 1998.

Holben, B, N., Tanre, D., Smirnov, A., Eck, T. F., Slutsker, I., Abuhassan, N., Newcomb, W. W., Schafer, J., Chatenet, B., Lavenue, F., Kaufman, Y. J., Castle, J., Setzer, A., Markham, B., Clark, D., Frouin, R., Halthore, R., Karnieli, A., O’Neill, N. T., Pietras, C., Pinker, R. T., Voss, K., and Zibordi, G.: An emerging ground-based aerosol climatology: Aerosol optical depth from AERONET, J. Geophys. Res., 106, 12 067-12 097, 2001.

IPCC: Climate Change 2007: the physical science basis, contribution of Working Group I to the Fourth Assessment Report of the Intergovernmental Panel on Climate Change, edited by: Solomon, S., Qin, D., Manning, M., Chen, Z., Marquis, M., Averyt, K. B., Tignor, M., and Miller, H. L., Cambridge University Press, Cambridge, UK and New York, NY, USA, 996 pp., 2007.

Kaufman, Y. J., Tanré, D., and Boucher, O.: A satellite view of aerosols in the climate system, Nature, 419, 215-223, 2002.

Lyamani H., Olmo, F. J., Alcántara A., and Alados-Arboledas, L.: Atmospheric aerosols during the 2003 heat wave in southern Spain II: microphysical columnar properties and radiative forcing, Atmos. Environ., 40, 6465-6476, 2006.

Liao, H. and Seinfeld, J. H.: Radiative forcing by mineral dust aerosols: sensitivity to key variables, J. Geophys. Res., 103, 31 637-31 645, 1998.

Ramanathan, V., Crutzen, P. J., Kiehl, T., and Rosenfeld, D., Aerosols, Climate, and the Hydrological Cycle, Science, 294(5549), 2119-2124, 2001.

Ramos, A. M.: Modelação Numérica do Transporte de Poluentes Atmosféricos em Portugal e suas Relações com as Condições Meteorológicas, Ph.D. Thesis, Department of Physics, University of Évora, Portugal, 233 pp., 2006.

Reid, J. S. and Hobbs, P. V.: Physical and optical properties of young smoke from individual biomass fires in Brazil, J. Geophys. Res., 103, 32 013-32 031, 1998.

Rolph, G. D.: Real-time Environmental Applications and Display sYstem (READY) NOAA Air Resources Laboratory, Silver Spring, MD, USA, available at: http://www.arl.noaa.gov/ready/ hysplit4.html (last access: February 2007), 2003. 
Russel, P. B., Redemann, J., Schmid, B., Bergstrom, R. W., Livingston, J. M., McIntosh, D. M., Ramirez, S. A., Hartley, S. A., Hobbs, P. V., Quinn, P. K., Carrico, C. M., Rood, M. J., Ostrom, E., Noone, K. J., von Hoyningen-Huene, W., and Remer, L.: Comparison of aerosol single scattering albedos derived by diverse technique in two North Atlantic experiments, J. Atmos. Sci., 59, 609-619, 2002.

Satheesh, S. K.: Aerosol radiative forcing over land: effect of surface and cloud reflection, Ann. Geophys., 20, 2105-2109, 2002, http://www.ann-geophys.net/20/2105/2002/.

Silva, A. M., Costa, M. J., Elias, T., Formenti, P., Belo, N., and Pereira, S.: Ground based aerosol monitoring at Évora, Portugal, Global Change Newsletter, 56, 6-9, 2003.

Takemura, T., Nakajima, T., Dubovik, O., Holben, B. N., and Kinne, S.: Single scattering albedo and radiative forcing of various aerosol species with a global three dimensional model, J. Climate, 15, 333-352, 2002.
Tegen, I. and Lacis, A. A.: Modeling of particle size distribution and its influence on the radiative properties of mineral dust aerosol, J. Geophys. Res., 101, 19 237-19244, 1996.

Vermote, E. F., Tanré, D., Deuze, J.-L., Herman, M., and Morcrette, J.-J.: Second simulation of the satellite signal in the solar spectrum: an overview, IEEE T. Geosci. Remote, 35, 675-686, 1997a.

Vermote, E. F., Tanré, D., Deuze, J.-L., Herman, M., and Morcrette, J.-J.: Second simulation of the satellite signal in the solar spectrum (6S), 6S User's guide Version 1, NASA-GDFC, Greenbelt, Maryland, 134 pp, $1997 \mathrm{~b}$.

Verver, G., Raes, F., Vogelezang, D., and Johnson, D.: The 2nd aerosol characterization experiment: meteorological and chemical overview, Tellus B, 52, 126-140, 2000. 